\title{
E-Commerce Benefits, Challenges and Growth in India
}

\author{
Farhad Alam \\ Analyst, eBay, Shanghai, China
}

\author{
Manavver Ali \\ Lecturer, HCT, Muscat, Oman
}

\begin{abstract}
E-commerce (electronic-commerce) is a business-method between sellers-and-buyers to exchange "goods" and "services" uses electronics network to process cash, frequently and no obstacle of time-duration and distance. Demands of online business is growing continuously since around ten years and is likely to proceed and even growin at this pace. In the near future, the boundaries between "traditional" and "electronic" commerce will turn out to be increasingly blurred and day to day many organizations pass parts of their activities over the internet. The e-commerce area in India is growing very fast due to the excessive penetration of web and superior digital devices. However, the current growthof e-commerce in India is still steps behind than that $o$ other developed countries. The great benefits-of-e-commerce reduces the geographical boundaries, attracts new clients very easily and quick by uses of any search engines reduces preservation and

Rental costs, increasing sales day to day, full-size business reach, simplified ordinary payments, direct transactions via net banking, credit card and debit card etc. nevertheless there are dealing with many fundamental troubles and challenges of online seller and buyer routes. Fraudulent is the biggest problem in online money processing and its increasing day-to-day. There are many types of fraud like phishing, identity theft, pagejacking, advanced fee and wire transfer frauds, merchant identity fraud etc.
\end{abstract}

\section{Keywords}

E-commerce, On-Line Shopping, Growth, Benefits, challenges

\section{INTRODUCTION}

E-commerce is quickly transforming the way in which enterprises are cooperating among each other as well as with customers and governments. and it is growing popular in an emerging economy. it needs the digital goods for caring out their transactions. digital goods are goods that can be delivered over a digital network. India have many ecommerce companies like Amazon, Flipkart, Myntra, Paytm, and Snapdeal etc. but Amazon and Flipkart are more popular in India.

E-commerce has been hailed by many as an opportunity for developing countries to gain a stronger foothold in the multilateral trading system. e-commerce has the ability to play an instrumental role in helping developing economy's benefit more from trade. E-commerce will continue to evolve and expand with growth of internet computers laptop tablet devices and smart phones.

The exponentially growth of social media in recent years the conversation between businesses and consumers has become more engaging making it easier for transactional exchanges to happen online. Internet retailers continue to strive to create better content and a realistic shopping experience with technologies like augmented reality. with mobile commerce gaining speed more users are purchasing from the palm of their hand.

The designed technologies is playing very important role to improve on-going transactions using the internet have evolved as speedily. However as of yet not achieved an ideal world of painless and secure transactions utilizing the internet as unresolved privacy issues of the purchaser have impeded the further development of the technologies. e-commerce has been hailed by many as an opportunity for developing countries to gain a stronger foothold in the multilateral trading system. E-commerce has the ability to play an instrumental role in helping developing economics benefit more from trade[11].

The worldwide business community is quickly moving in the direction of business-to business b2b e-commerce. the buyers gain a clear advantage when the internet gives them access to the global market by which they can compare prices across regions find out whether prices vary by order fragmentation and get awareness about substitute products. due to transparency of the market customer can compare the services of various e-commerce sites easily. for instant in case of ecommerce the competitors are one click away from customer. if clients are not happy with the products prices or services offered by e-commerce site, they are able to change much more easily than in the physical. from the seller's point of view, they don't need to have physical existence of shop[11].

\section{ON-LINE SHOPPING PROCESS}

The transactions process of On-line Shopping(OL-Shop). Customer who is buying the items or selling the items are basically the same as in the normal shopping. Customers who want to place the order to buy the item. First should create the account on website of the company where want to buy the product and There after getting goods. Mostly OL-Shop having the facility to pay the money by e-banking, debit card, credit card and some using prepaid Cash cards, DD or demand draft and very few peoples like to go for mobile payment etc. Finally, when selling physical goods, any good delivery company (DC) is also necessary. The whole process of an OL-Shop transactions may be divided in following phases in Fig 1.

- Customer browse the website and try to search the required item from merchant's website. Select the item.

- Fill Cart and start checkout to validate. Then provide shipping address and Payment information what payment method customer will use.

$\checkmark$ Confirm the purchase and pay the amount

- Delivery process will start to deliver the item and customer will get the email or message on registered phone and email as well.

- Customer will continue to get the update about tracking the item in Fig 2. 


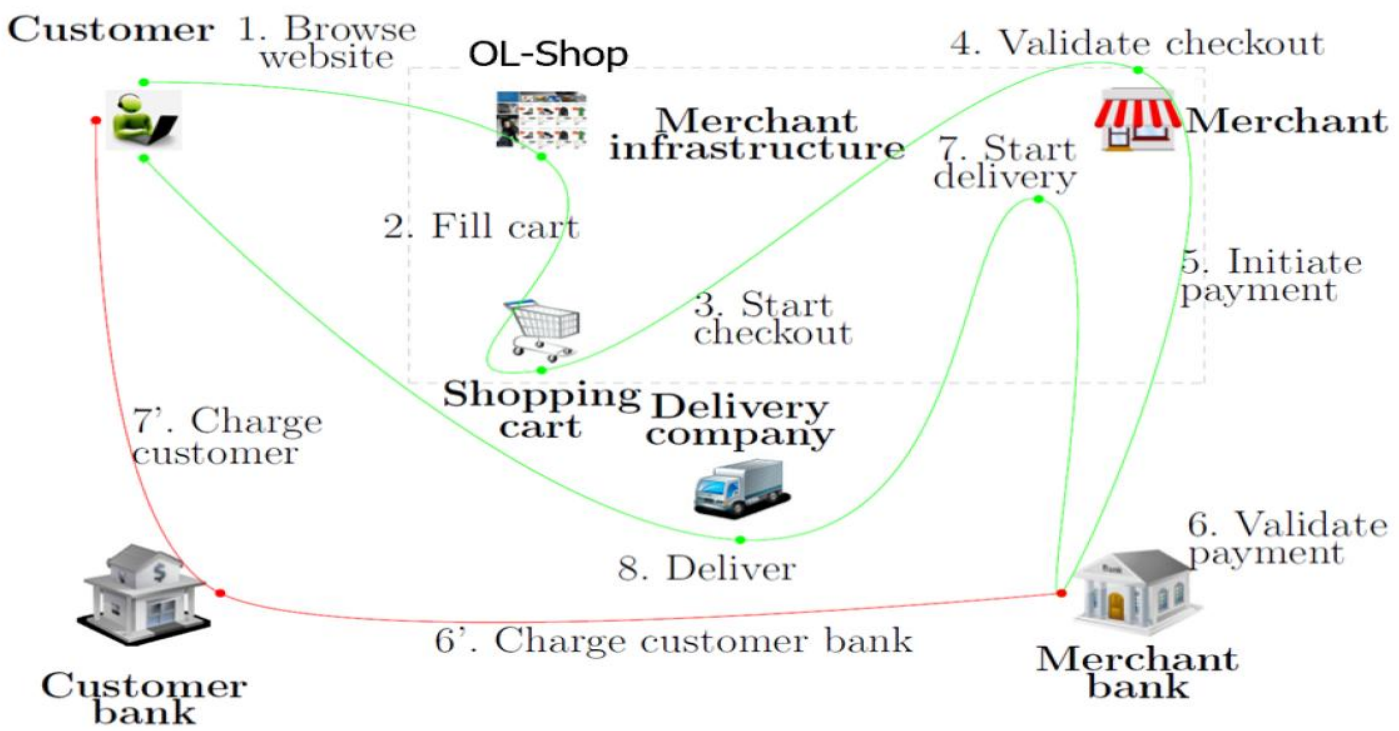

Fig 1: Overview of On-Line Shopping Process[4].

Arriving 25 December - 27 December

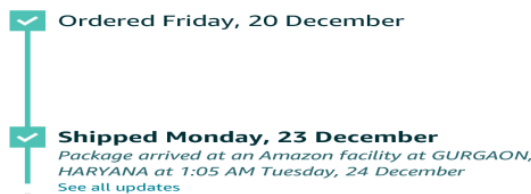

Out for delivery

Fig 2: Item tracking after place the order.

\section{E-COMMERCE GROWTH}

In India, there is a great deal of interest in e-commerce. It did not spread widely in the past due to various economic, infrastructural and many other factors. Especially big problems of internet in rural areas but After the starter of 3G/4G technology. And now a days have many companies providing good internet packages at economically price like Jio, airtell,Vodafone and idea etc. and e-commerce has been growing rapidly now because peoples are able to access internet easily as in past. According to "International Journal of Advanced Research Foundation" Digital marketing in India had the golden period of the Internet area between the 2013 to 2018 and growth adoption for E-Commerce, Social Media, Internet Advertising, Online Content, Search, and Services linking digital marketing.

Fig 3 showing the growth of Media, Digital and Mobile Internet Ad Spending in India. Digital marketing overview tells that Social media has been playing a supportive role to marketing. Over the years, it has been noticed that $92 \%$ of social media users are from the mobile-devices. This permits the size of digital marketing industries and enlarges the horizon of online advertising India [5].

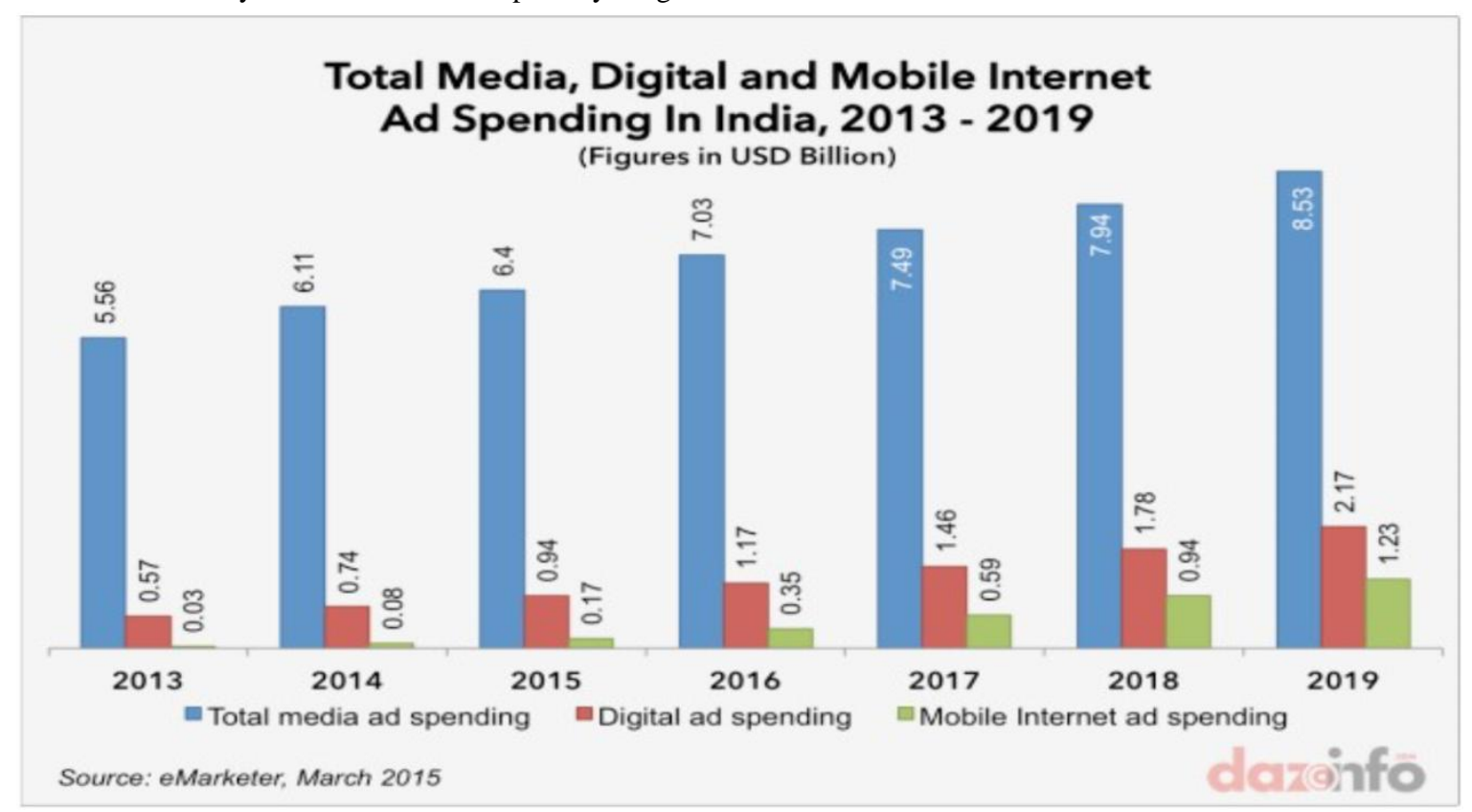

Fig 3: Growth of Media, Digital and Mobile Internet Ad Spending in India From 2013 To 2019[5]. 


\subsection{Internet-Users Growth}

Information of India internet-users from 2015 to 2023. India had 483 million internet-users in 2018. The Fig 4 is predicted internet-users growth to 664.4 million in 2023. India already is the second largest online market worldwide after China. Mostly India's internet-users are uses mobile phone because mobile is using to do the communication as well to access to any website to do online shopping. Who take benefit of cheap alternatives. to avoid expensive landline phone that need desktop PCs. In 2016, India had around 320.57 million mobile-phone internet-users and forecasts estimate 492.68 million Indian mobile-phone internet-users by 2022[6].

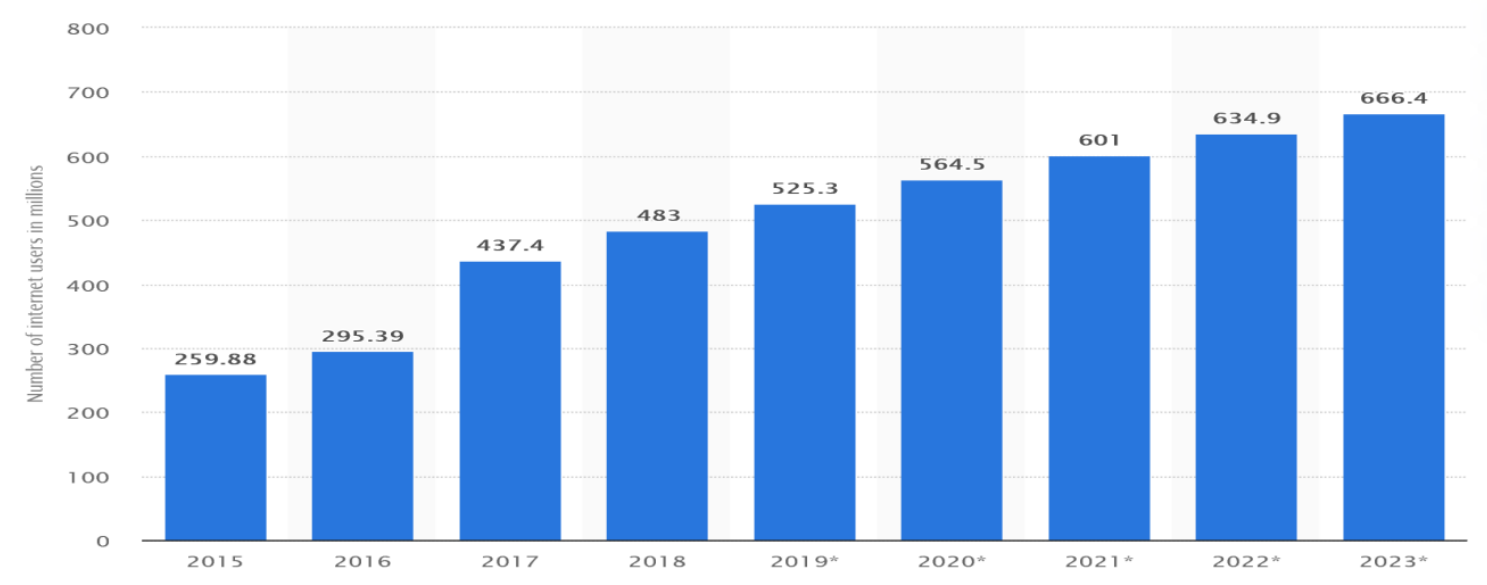

Fig 4: No Of Internet Users In India From 2015 to 2023[6].

\subsection{Digitals-Buyers Growth in India}

The e-commerce sector in the Asian region has seen a flourishing in the current years. the south Asian-country like India had the fastest rising online-retail-market in 2019. the number of Indian digital buyers(noidbs) across the country was estimated to be approximately 330 million in 2020 . the Fig 5 suggests that almost 71 percent of internet-users in the region will have ol-shopping for the mentioned time period. the sector is driven by personalized advertisements attractive discounts quick delivery and return infrastructure and a high penetration rate of smartphones. this retail ecosystem combined with the comfort of being at home and getting all your choices delivered to your doorstep has turned the tables for the e-commerce sector quite significantly. major consumption in this area came from the male population in the country in 2015 where amazon was preferred the destination for scouting of products. customized apps and experiences had their influence as well. almost 50 percent of the citizens had used a mobile device for the purchase of goods or services in 2016278083 [7]

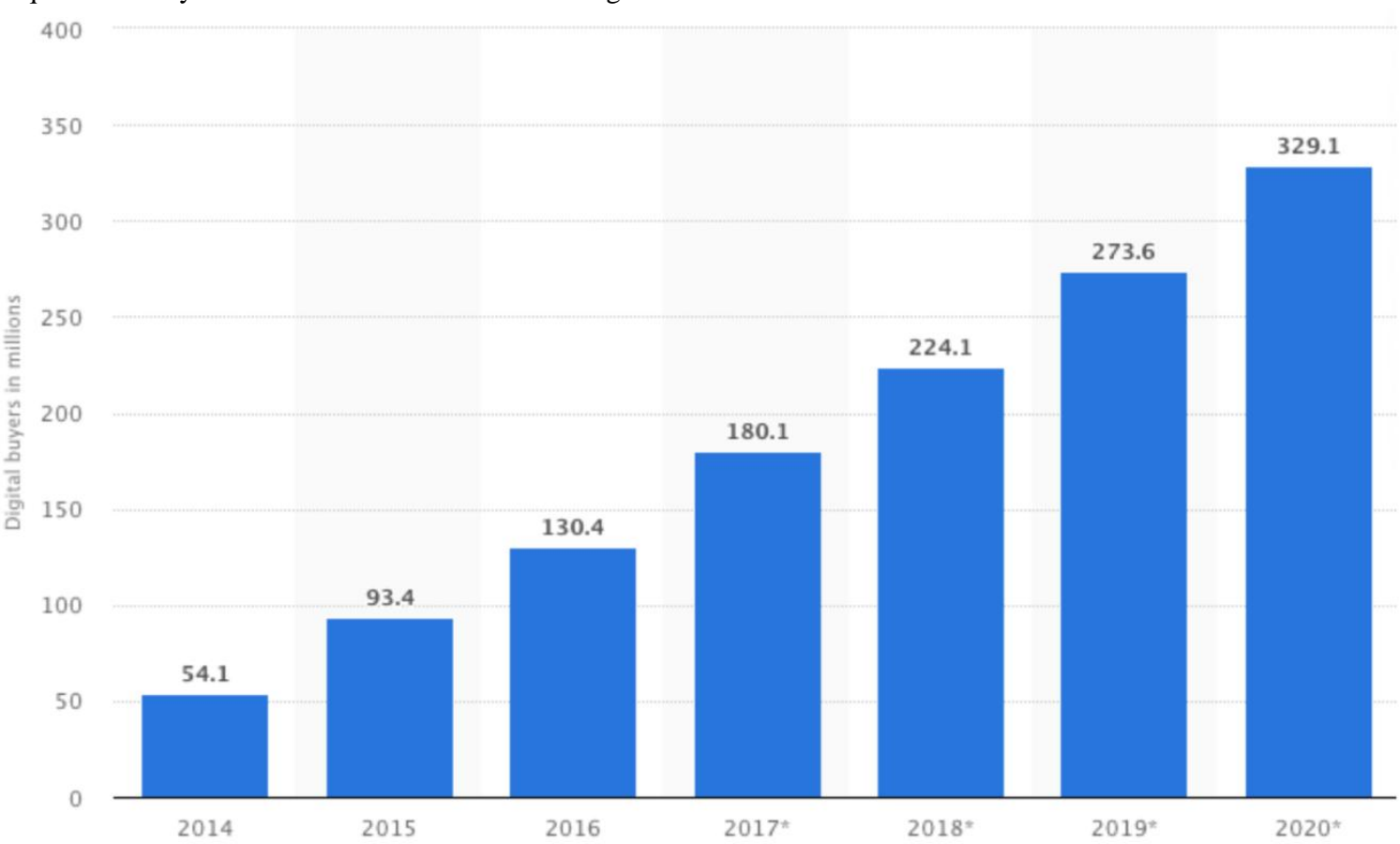

Fig 5: Number Of Digitals Buyers In India In Millions[7].

\subsection{Internet Usages in the Aisa Pacific}

When it comes to the demographic of Asia Pacific's internet users, the region has more male than female internet users. Individuals in the Asia Pacific region spent about 150 minutes on using the internet daily with figures also indicating that more than half of the time was spent on mobile devices instead of desktop devices. 
Mobile internet has been an area which has undergone a strong development across the globe in recent years. Mobile internet penetration in the Asia Pacific region was at 45 percent in 2018 and was forecasted to reach 62 percent by 2025. This had a significant impact on mobile commerce and mobile advertising in the region where e-commerce conversion of app transactions was highest compared to desktop and mobile web transactions.
As of January 2019, China ranked first with around 802 million internet users while India achieved second place with 560 million internet users. China and India were not only leading within the Asia Pacific region, but also worldwide. The Asia Pacific region had the largest number of internet users worldwide, reaching nearly 2.1 billion in 2018 . However, internet penetration in Asia was still below global average in that year[8].

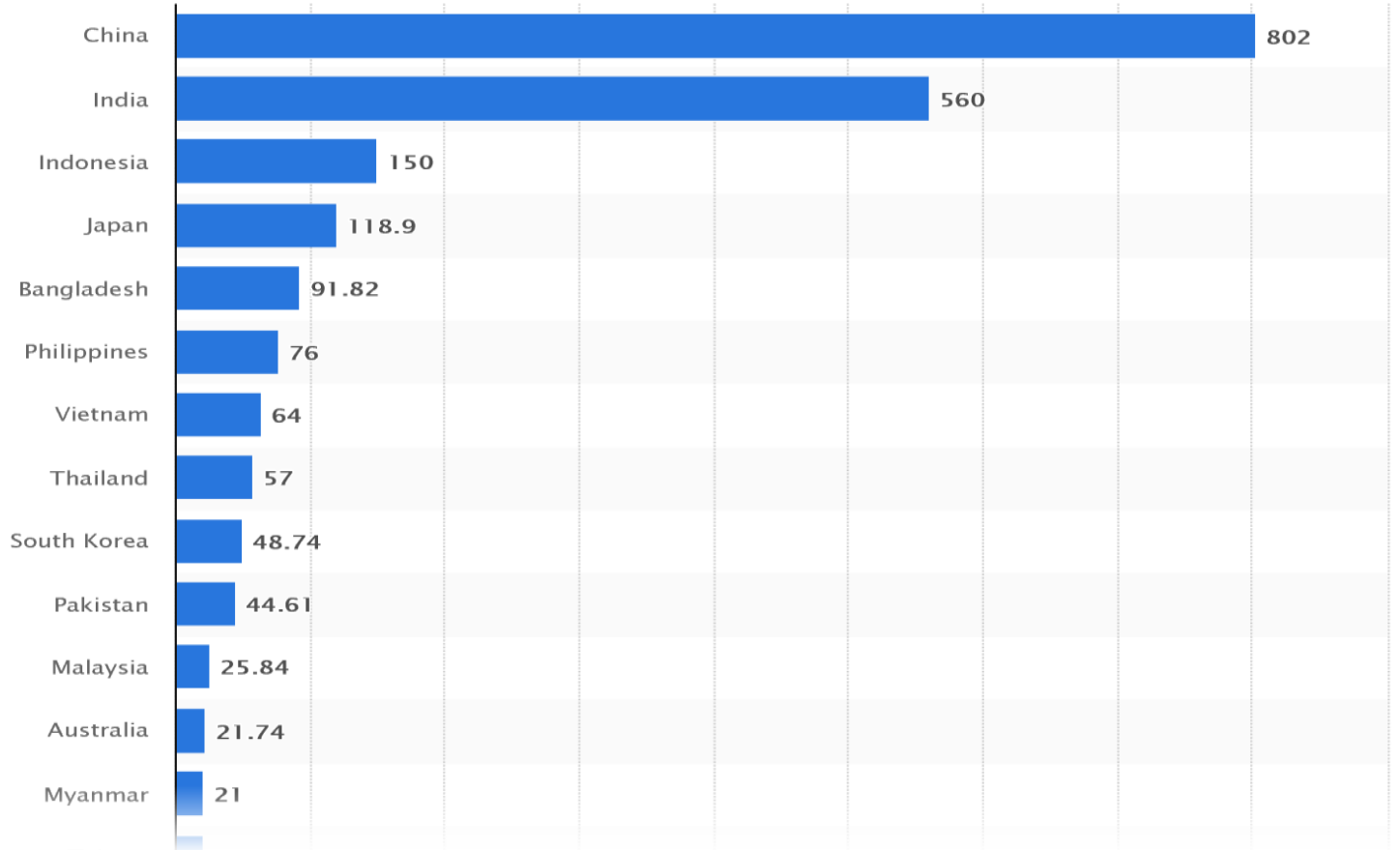

Fig 6 : Number Of Internet Users In The Asia-Pacific Region As of January 2019, By Country (In Millions)[8].

\subsection{E-Commerce Sites in India}

India 2019 Top-10 e-Commerce platform with estimated traffic[9] in below Table. Columns of table Ind-eC-Plt is Indian e-Commerce Platform),EstMTIM is Estimated Monthly Traffic in Millions and PRCOT is Percentage of Estimated traffic in Millions[9].

Table 1: India 2019 Top-10 E-commerce platform with estimated traffic

\begin{tabular}{|l|l|l|}
\hline Ind eC Plt & EstMTIM & PRCOT \\
\hline Paytm Mall & 5.9 & $1 \%$ \\
\hline 1mg & 7.45 & $1 \%$ \\
\hline Nykaa & 13.7 & $2 \%$ \\
\hline Firstcry & 27.8 & $4 \%$ \\
\hline BookMyShow & 43.4 & $5 \%$ \\
\hline IndiaMart & 42.8 & $5 \%$ \\
\hline Snapdeal & 83.5 & $10 \%$ \\
\hline Flipkart & 221.5 & $27 \%$ \\
\hline Amazon India & 365.5 & $45 \%$ \\
\hline
\end{tabular}

\section{BENEFITS OF E-COMMERCE}

Advantages of online-shopping is significant increase and time saving and easy to access from any place in the globe and customer can place the order at any time.

\subsection{Advantages of E-Commerce for Buyers}

- Transaction costs for participating exchange in a market is reduced.

- No need physical interaction with business organization and transaction can be done 24 hours-a-day.

- Customer can access information very easy and can check the item related information on many websites at the click of a button.

- All the sales and purchases

- can be performed from home or working place or from any place where customer want to buy any products.

- If company is not giving good service then customer can easily the change the company at any time.

- Product can buy any where which is not available in the local or nation market, its proving a wider range of access to product than before.

- Before buy the product, customer can review the comment to make sure about product qualities.

4.2 Advantages of E-Commerce For Sellers.

- Easy to start e-commerce because cost is low.

- Easy to reach new customers.

- Increasing revenue.

- Reducing operation and maintenance costs through internet. 
- Easy to be developed good relationship between customer and supplier.

- Easy to Improves speed of the process of selling.

- Easy to improves internal and external communication.

- Easy to Develops the company image and brand.

- Easy to meet customer where they want to buy the product.

\subsection{Advantages of E-Commerce For Society}

- No need to travel to shop to buy a product, so reducing the traffic on road and low air pollution.

- Help to reduce the cost of products, so price of product can also affordable.

$\checkmark$ E-commerce is providing the service in rural areas.

- E-commerce supports to Government to deliver public services such as education, healthcare, social services at a low cost and in an better-quality manner.

\section{CHALANGES OF E-COMMERCE}

In E-commerce, Buyers and Sellers facing major challenges when doing the business transactions via internet are as follows.

Synchronization between public and private corporation is not grow the business of e-commerce. Joint initiative of public and private is required to develop the e-commerce business. This Joint initiative bring reliability inside people, which is required for booming the ecommerce business.

The most common problem of e-commerce portal (website) is not having enough cyber security because there is lack of system security, reliability standard and due to lack of communication protocol. If then e-commerce website is hacked by someone else and customer loses their money.
In developing countries like India having the culture of buying the product by bargaining the cost with sellers. In case of online shopping is not easily possible to bargaining the cost of products to down the price because of lack of infrastructure in developing countries.

Big challenges faced by e-commerce in rural areas have limited outreach in rural areas. There are lot-off problem facing host problems, internet performance issue, language barrier, road transport infrastructure, village economy, Law and order issues, Limited credit card accessibilities and criminal activities etc. And instead of this still having many other issues like courier services is not good and buyers of rural areas mostly time is not getting delivery at same address provided of village and small town. Courier service delivered the products at nearest city and even not informing the buyers so there so many issues to get the product in rural areas.

In addition. The above challenges, the developing economy like India also faced the following

- Poor knowledge and awareness due to lack of education.

- Poor concept of online marketing, less marketing or promote.

- Internet coverage arena is limited and getting issue for online transactions.

- Online security and Tax structure is not good.

- Communication is haphazard over the country

- Lack of trustable business and enterprise and

- Lack of experience of meeting directly with merchant and customer.

- Fear, touch and feel's factor.

- Cash of delivery, Logistics and Shipment services.

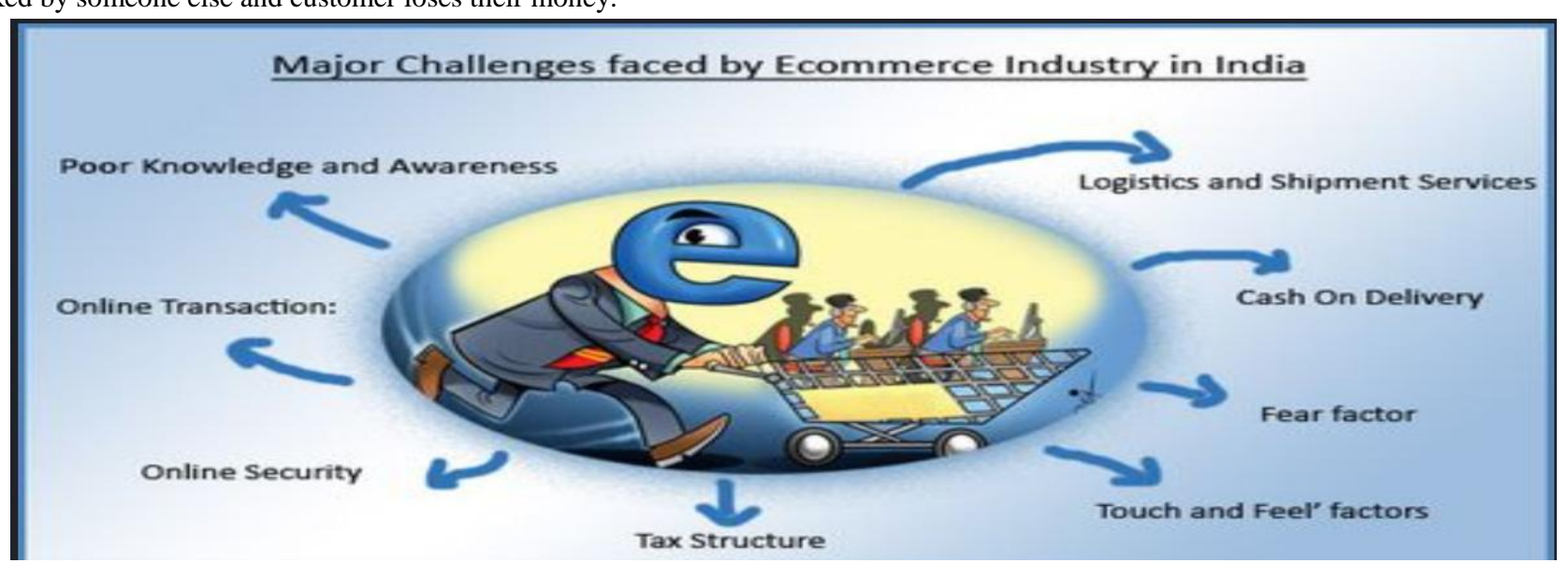

Fig 7: Major Challenges faced by E-commerce Industry in India[10]

\section{DISCUSSION AND FINDING}

DISCUSSION: Introduced the e-commerce, how the on-line business is starting and peoples is liking it more-more and how the item is getting easy to buy online as compared the buy from market. Explained about online-shopping process how can order the item and to pay money and what method are using to pay the money. How can track the item.

DISCUSSION: The growth of Media, Digital and Mobile Internet Ad Spending and India had the golden period of the Internet area between the 2013 to 2018. Over the years, it has been noticed that $92 \%$ of social media users are from the mobile-devices. Total media ad spending 8.55 Billion USD, Digital Ad spending is 2.17 Billing USD and Mobile internet Ad spending 1.23 Billion USD in 2019 according to source[5].

DISCUSSION: India internet-users from 2015 to 2023. India had 483 million internet-users in 2018. The Fig 4 is predicted internet-users growth to 664.4 million in 2023. India already is the second largest online market worldwide after China and Digitals Buyers in India had the fastest rising online-retailmarket in 2019. the number of Indian digital buyers(noidbs) across the country was estimated to be approximately 330 million in 2020 in Fig 5. 
FINDING: In Fig 8: find out the relation between growth rate data and percentage of Indian internet users and digitals buyers. In below Table took the data from statistic as in above Indian internet users[6] and digital buyers[7].Columns of below table. In table column GPODS percentage in 2016 is $40 \%$ and then $38 \%$ and continue decreasing and in column NOIIUS number of Indian internet users also decreasing and percentage decrement from 2018 in both Internet and digital buyers is $2 \%$. And already trace the graph between Internet users and digital buyer. So according to trend of percentage growth rate is continually decreasing in both

and if internet users are increasing and then digital buyer also increasing.

Years : YRS

Numbers Of Indian Internet Users : NOIIUS

Numbers Of Indian Digital Buyers : NOIDBS

Growth Percentage Of Digital Buyers: GPODBS

Growth Percentage Of Indian Internet Users: GPOIIUSS

Table 2 : Growth Percentage of NOIIUS and GPODBS

\begin{tabular}{|c|c|c|c|c|}
\hline YRS & NOIIUS & NOIDBS & GPODBS & GPOIIUS \\
\hline 2015 & 259.88 & 93.4 & & \\
\hline 2016 & 295.39 & 130.4 & $40 \%$ & $14 \%$ \\
\hline 2017 & 437.4 & 180.1 & $38 \%$ & $48 \%$ \\
\hline 2018 & 483 & 224.1 & $24 \%$ & $10 \%$ \\
\hline 2019 & 525.3 & 273.6 & $22 \%$ & $9 \%$ \\
\hline 2020 & 564.5 & 329.1 & $20 \%$ & $7 \%$ \\
\hline
\end{tabular}

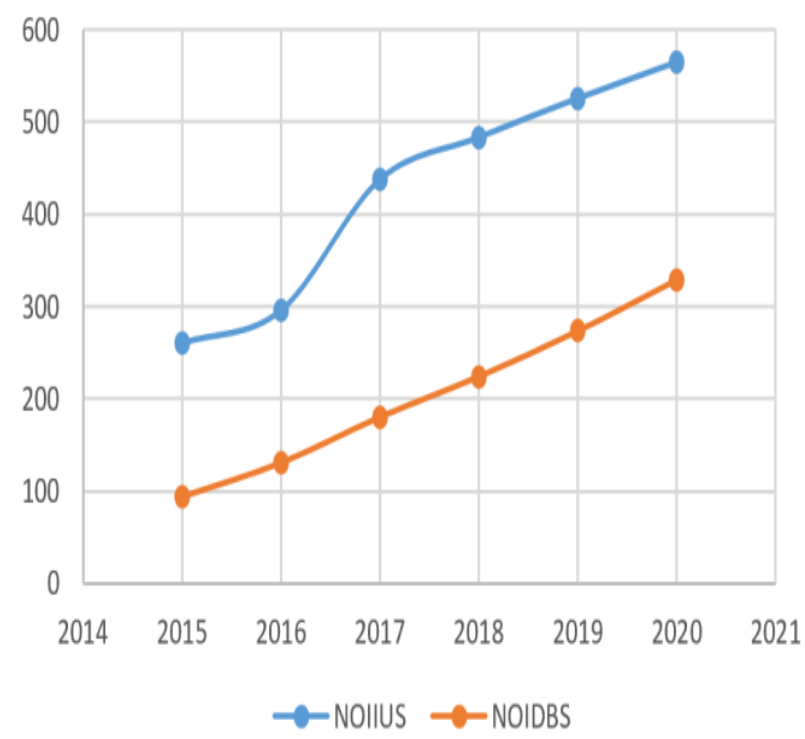

Fig 8: Growth of NOIIUS and NOIDBS

DISCUSSION: The percentage of Top-10 e-commernce platform in India with Estimated Monthly Traffic in Millions in Fig 9. According traffic amazon.in is the biggest on-line shopping platform in India and its monthly traffic percentage is $45 \%$. Its providing good services in India and that's why having no of digital buyer more than other e-commernce sites. Paytm Mall is having less no of buyers in India.

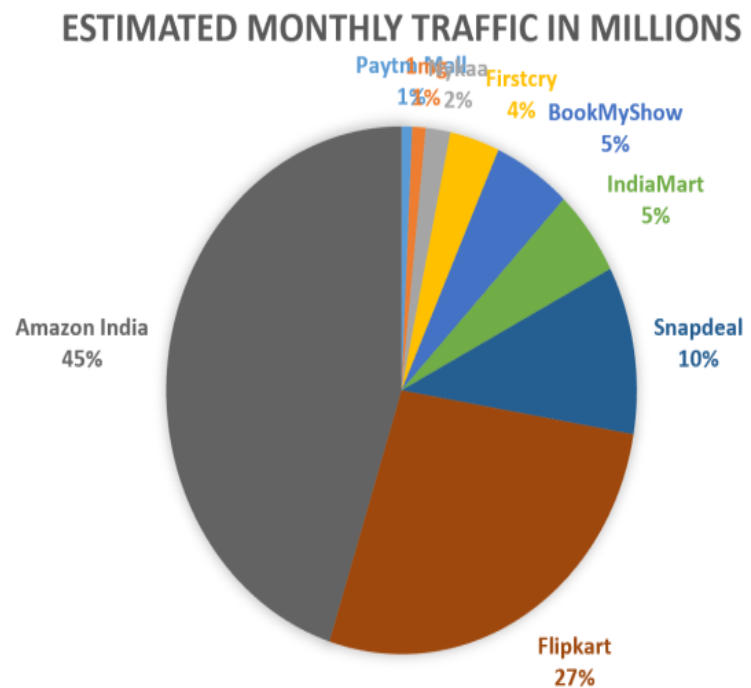

Fig 9: Top-10 E-commerce Platform In India With Estimated Traffic[9]

\section{CONCLUSION AND RECOMMENDATIONS}

The e-commerce business is continue growing and it will be a leader with popularity in electronic business world in the upcoming years. The emergence of technology, Economies around the world have benefitted and new ideas have been implemented to reach out to consumers. India is no different and so embraced a phenomenon named E-Commerce to such an extent that is significant for the economy and organizations to thrive these days. E-Commerce has brought a massive change to the consumers and is responsible for growth and employment as well.

This research has completely focused on how E-Commerce has evolved during the last six years and contributed. About a decade back, the success of E-Commerce was unthinkable but the impact it created in the last decade was something that couldn't have been easily estimated. The research explores how E-Commerce as an industry has grown over the years, how the digital buyers growing with internet users. Study also reveals the extent of benefits and challenges of E-Commerce for the Indian economy

The e-commerce revolution has fundamentally changed the business of transaction by giving new opportunities and breaking borders easily. In India, it has strongly impacted the traditional business system and changing the life of people by making it easier. While it gives

benefits to customer and seller, e-commerce gives challenges to traditional business for competitive position. The Developing countries face many problems that affect the successful implementation of e-commerce with the help of comparing with developed country. When the internet cost will be low then the e-commerce will flourish easily and specially in rural area still internet speed is not good and peoples are facing big problem to open the e-commerce site to place the order to buy the products.

E-commerce company should improve the customer holding tactic they should improve the services for customers from rural areas. They should add more and more items for shopping and have a higher conversation rate and generate the more revenue each time when customer will visit on your site. Displace the icon to show your site more trustworthy and 
should be focus on cyber security to avoid the fear of customer to be cheat. Offer more discounts specially during special times of the year, such as the holidays of different festival like Deepawali, Holi, Christmas day, Eid and BakraEid etc.Can help to improve the sales and should be accept different option of payments. During special times of the year, such as the holidays, can help you improve sales.

\section{REFERENCES}

[1] Chavan, J., 2013. Internet Banking- Benefits and Challenges in an Emerging Economy. International Journal of Research in Business Management, Vol. 1(1), pp. 19-26.

[2] Clayton, T., et al 2002. Electronic Commerce and Business Change.

[3] Ray, J.S., 2011. Leveling E-Commerce Opportunities for Developing Countries. SMC University. Swiss Management Centre,Transknowlogy Campus.

[4] Jesus, D., Seung, G.C., David, A., Angelos, D., Keromytis3, F.B. and Moti, Y., 2015, September. Privacy Threats in E-Shopping and DOI:282122381.

[5] DigitalMarketing:https://www.digitalvidya.com/blog/gro wth-of-digital-marketing-industry-in-india.

[6] Sanika, D., 2019. India: number of internet users 20152023.

[7] StatisticsofDigitalBuyers20142020:https://www.statista.c om/statistics/251631/number-of-digital-buyers-in-india.

[8] Ella, Z.D., 2019, November. Number of internet users in selected Asia-Pacific countries 2019.

[9] Top 10 e-commerce sites in India 2019: https://disfold.com/top-e-commerce-sites-india.
[10] Major challenges faced by ecommerce industry in India 2012: http://www.emavens.com/blog/major-challengesfaced-by-ecommerce-industry-in-india.

[11] Abdul, G.K., 2016, Electronic Commerce: A Study on Benefits and Challenges in an Emerging Economy, Volume 16 Issue 1 Version 1.0 ISSN: 2249-4588 \& Print ISSN: 0975-5853.

[12] Nanehkaran, Y. A., 2013. An Introduction to Electronic Commerce. International Journal of Scientific \& Technology Research, Vol. 2(4), pp.190-193.

[13] Nanehkaran, Y. A., 2013. An Introduction to Electronic Commerce. International Journal of Scientific \& Technology Research, Vol. 2(4), pp.190-193.

[14] Molla, A. and Heeks, R., 2007. Exploring Ecommerce benefits for businesses in a developing country. The Information Society.

[15] Laudon, K. C., and Traver, C.G., Introduction to Ecommerce: business. technology. society. Fifth Edition.

[16] Harris, L. and Spence, L. J., 2002. The ethics of Banking. Journal of Electronic Commerce Research, Vol. 3(2).

[17] Salnoske, K., 1997, Building Trust in Electronic Commerce, Credit World, Vol. 85 No 6. pp. 9-11.

[18] Turban, E., Lee, J., King, D., Chung, M., 2000, Electronic Commerce: A Managerial Perspective, Prentice Hall International, Inc. New Jersey.

[19] Rajasekar, S. and Sweta, A., 2016, March. A study of Impact of India-Commerce on India's e-Commerce Vol. 6, Issue, 03, pp. 7253-7256, Coimbatore, March,2016, pp. 7253-7256,ISSN- 2230-9926. 